\title{
Comparative study between conventional adenoidectomy and adenoidectomy using micro-debrider
}

\author{
Essam A. Abo Elmagd, Mahmoud S. Khalifa, Beshoy K. Abeskharoon* “id and Abdelrahman A. El Tahan
}

\begin{abstract}
Background: Adenoidectomy is a common ENT procedure. This article aims to evaluate micro-debrider-assisted adenoidectomy as a substitute for the conventional curettage method.

Results: The study aimed to compare between two study groups: micro-debrider-assisted adenoidectomy (group A) and conventional adenoidectomy (group B). The average time needed in group A was 34.1 min while it was $22.83 \mathrm{~min}$ in group $B(p<0.001)$. The average amount of blood lost in group A was $29.57 \mathrm{ml}$ and $16.67 \mathrm{ml}$ in group B ( $p<0.001)$. The resection was nearly complete in group $A$, while in group $B$, five $(16.66 \%)$ cases had more than $50 \%$ of the adenoid tissue left behind. Four cases in group B had damage to collaterals while in group A no major injuries were noted. Postoperative pain has only been studied in cases where adenoidectomy solely was done. Candidates in group A $(n=8)$ reported a pain score of 3.5-3.09 whereas candidates in group B $(n=11)$ reported a pain score of 2.75-2.55. The mean recovery time was 2.8 days in group $A$ and 8.23 days in group $B(p<0.001)$.

Conclusions: Endoscopic adenoidectomy using micro-debrider is both an effective and safe adenoidectomy tool. The strengths of this technique include resection completeness, precise resection under vision, minor damage to collaterals, and a more rapid recovery period. Conventional adenoidectomy, however, scored better regarding lesser operative time and bleeding intraoperatively.
\end{abstract}

Keywords: Adenoidectomy, Conventional, Micro-debrider

\section{Background}

The adenoid represents as lymphatic tissue in the nasopharynx. Adenoids are situated in the midline on the roof and posterior wall of the nasopharynx [1].

Patients suffering from adenoid hypertrophy are presented with obstructive nasal breathing. This may or may not be accompanied by a chronic or acute infection of the adenoids [2]. A recent meta-analysis study demonstrated that the prevalence of hypertrophied adenoid in a randomized representative sample of children and adolescents was $34.46 \%$ [3].

Adenoidectomy, either alone or with tonsillectomy, is considered among the most performed procedures in

\footnotetext{
* Correspondence: beshoyk@gmail.com

Department of Otorhinolaryngology-Head and Neck Surgery, Faculty of Medicine, Aswan University, Aswan, Egypt
}

pediatric otorhinolaryngology [4]. Classical adenoidectomy is referred to as the curette adenoidectomy or conventional adenoidectomy (CA), which utilizes a curette for adenoids removal [5]. The conventional adenoidectomy procedure that was first described by Meyer has been a very popular method of adenoidectomy for years [6]. Most of surgeons usually do it blindly, without direct visualization of the nasopharynx, relying on finger palpation of the adenoid tissue [7]. In spite of being liked by many surgeons, some might prefer visualization of the adenoid tissue in addition to surrounding structures before starting curettage. Postoperative complications such as insufficiency of the velopharyngeal valve, eustachian tube stenosis, and nasopharyngeal stenosis are not common but very difficult to manage whenever they happen. Moreover, adenoidectomy using this standard technique

\section{Springer Open}

(c) The Author(s). 2021 Open Access This article is licensed under a Creative Commons Attribution 4.0 International License, which permits use, sharing, adaptation, distribution and reproduction in any medium or format, as long as you give appropriate credit to the original author(s) and the source, provide a link to the Creative Commons licence, and indicate if changes were made. The images or other third party material in this article are included in the article's Creative Commons licence, unless indicated otherwise in a credit line to the material. If material is not included in the article's Creative Commons licence and your intended use is not permitted by statutory regulation or exceeds the permitted use, you will need to obtain permission directly from the copyright holder. To view a copy of this licence, visit http://creativecommons.org/licenses/by/4.0/. 
does not accomplish complete removal of the adenoid, especially in cases of intranasal or extension to posterior choana. Difficulty in access to other subsites of nasopharynx involved by adenoids like superiorly in the nasopharynx or around the eustachian tube [8]. The development of new technologies along the last few years has made an improvement in adenoidectomy procedure to develop the most effective technique of adenoidectomy [9]. Several techniques have been described, either alone or together with the classic $\mathrm{CA}$, to ensure adequate and complete removal of the adenoid tissue, along with adequate control of bleeding intraoperatively [9].

In the '90s of this century, the introduction of functional endoscopic sinus surgery (FESS) promoted the use of scopes and adenoidectomy using the endoscopic method became the natural evolution of the curettage adenoidectomy, allowing direct visualization, hence, better adenoid tissue removal [8]. The advent of powered instrumentation in endoscopic sinus surgery favored the usage of the debrider for a power-assisted adenoidectomy. That has been considered a great achievement in the technical aspect of adenoidectomy operation [10]. There is a variety of techniques of power-assisted adenoidectomy that can be divided into non-endoscopic techniques (using per-oral using the laryngeal or dental mirror) and endoscopic method to improve visualization [11]. The micro-debrider blade can be introduced transnasally (straight blades) or transorally (curved blades). Some surgeons used the power-assisted instruments in completing the whole procedure, while others utilized that for completion of adenoid tissue removal (combined techniques) [12].

\section{Methods}

The study was conducted on 60 patients who were enrolled from outpatients of the otorhinolaryngology outpatient clinic, and scheduled for adenoidectomy along the period from August 2018-August 2019. Tonsillectomy was scheduled along with adenoidectomy in patients who demonstrated indications for tonsillectomy as well. Patients were in 3-14 years old range regarding age category. All patients had symptoms of obstructive nasal breathing as a result of adenoid hypertrophy that was confirmed radiologically. Patients of other causes of nasal obstruction or cleft palate including submucus cleft palate and patients with a history of clotting disorders were excluded from the study. Patients were randomized to undergo either micro-debrider-assisted adenoidectomy, with or without the use of the endoscope (group A) or conventional adenoidectomy (group B). We used a simple random sampling method that included 30 patients for each group. Patients were included in the study in their chronological order of attending ENT outpatient clinic. Approval from the ethical committee and informed signed consent from patients' guards were issued. The comparison parameters were operative time, blood loss, and adenoid removal completeness and damage to collaterals as intraoperative indicators. Post-operative parameters were assessed including post-operative pain scoring and recovery time for both groups (Figs. 1, 2, 3, and 4).

\section{Results}

The study included patients aged 3 to 14 years old. The mean age of the patients was $7.27 \pm 2.36$ years in group A (micro-debrider-assisted) and $7.43 \pm 2.87$ years in Group B (conventional). The gender ratio was nearly equal in both groups. In the study groups, the most common presenting symptoms were nasal obstruction and sleep-disordered breathing. These were the main indications for surgery.

Analysis of intraoperative time consumed in group A (micro-debrider-assisted) subjects ranged from 22 to 70 min, the mean was of $34.1 \pm 8.44 \mathrm{~min}$. While in group B (conventional), the time consumed ranged from 20 to 28 min, the mean was $22.83 \pm 1.86 \mathrm{~min}$. There was a statistically significant difference ( $p$ value $<0.001$ ) between the two groups (Table 1). The average blood loss in group A (micro-debrider-assisted) was $29.57 \mathrm{ml}$ (range 26-35 ml) contrasted to an average blood loss of 16.67 $\mathrm{ml}$ (range 10-25 ml) in group B (conventional). Intraoperative blood loss was quantified by measuring the volume difference between irrigation fluid and fluid in the suction bottle postoperatively.

Post-adenoidectomy endoscopy was performed to look for residual adenoid tissue in both groups and residual adenoid tissue found was classified as follows: grade 1,

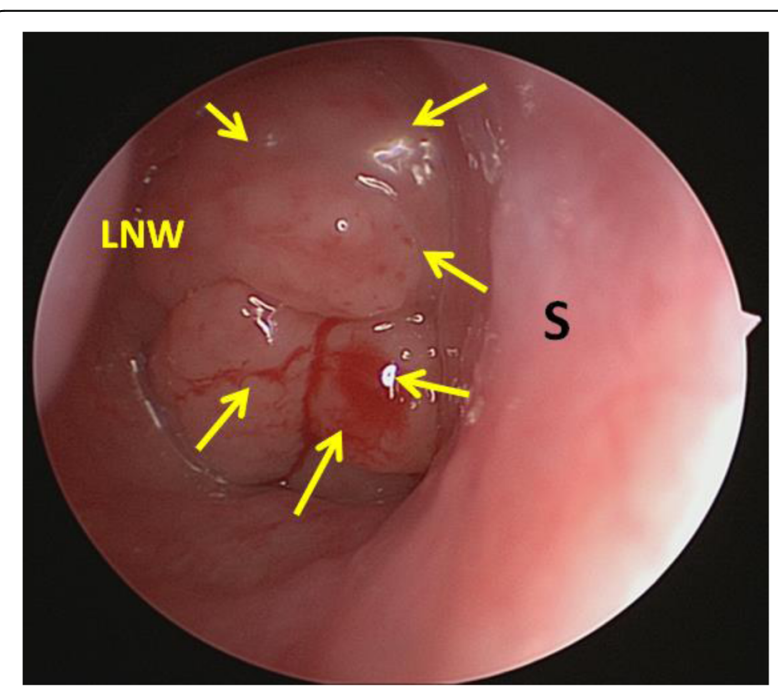

Fig. 1 Preoperative transnasal endoscopy examination demonstrating enlarged adenoids obstructing RT choana (arrows) [LNW, lateral nasal wall; S, nasal septum] 


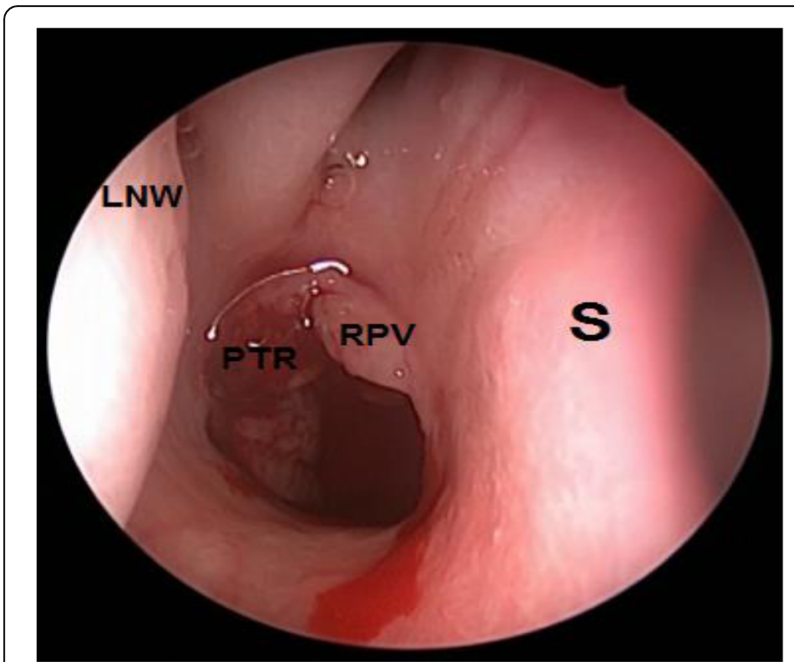

Fig. 2 Intraoperative transnasal endoscopy after CA reveals sizable residual adenoid tissues found at the posterior edge of the vomer (RPV) adjacent to the roof of the nasopharynx, and at the peritubaric region (PTR) on visualizing the RT choana. [LNW, lateral nasal wall; S, nasal septum]

less than 20\%; grade 2, 20-50\%; grade 3, more than 50\%. The post-procedure endoscopy showed that adenoid resection was almost complete in the endoscopic technique. Contradictory to this, more than 50 percent of adenoid tissue was left behind in 5 group $B$ cases and between 20 and 50 percent of adenoid tissue was left in an additional 18 cases (Table 2).

Post-operative endoscopy was also used to look for unintentional trauma/damage to collaterals after the adenoidectomy. In 2 cases, in group $\mathrm{B}$, the adenoid

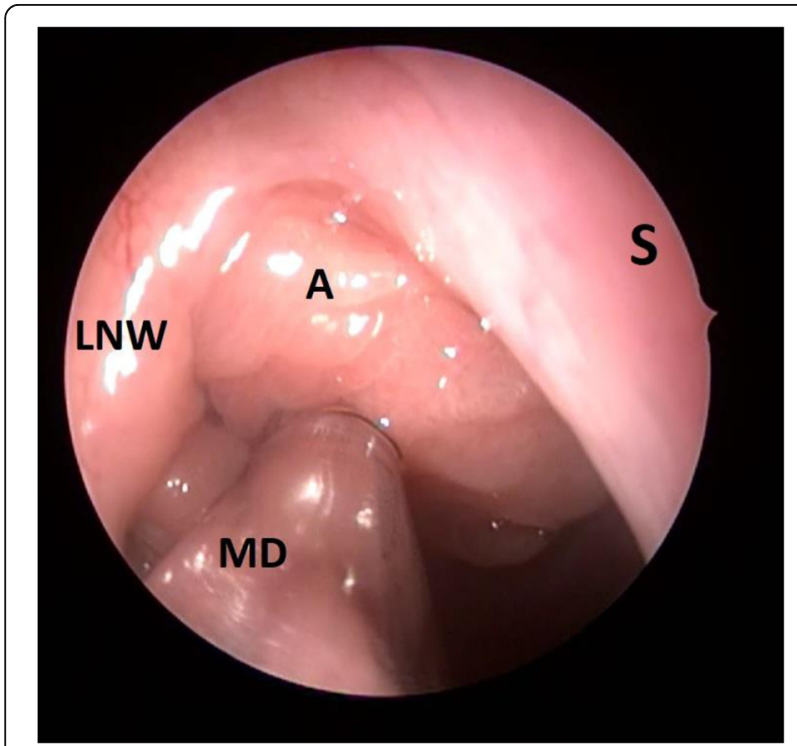

Fig. 3 Intraoperative transnasal endoscopy demonstrating shaving of the adenoid (a) using the micro-debrider (MD) [LNW, lateral nasal wall; S, nasal septum]

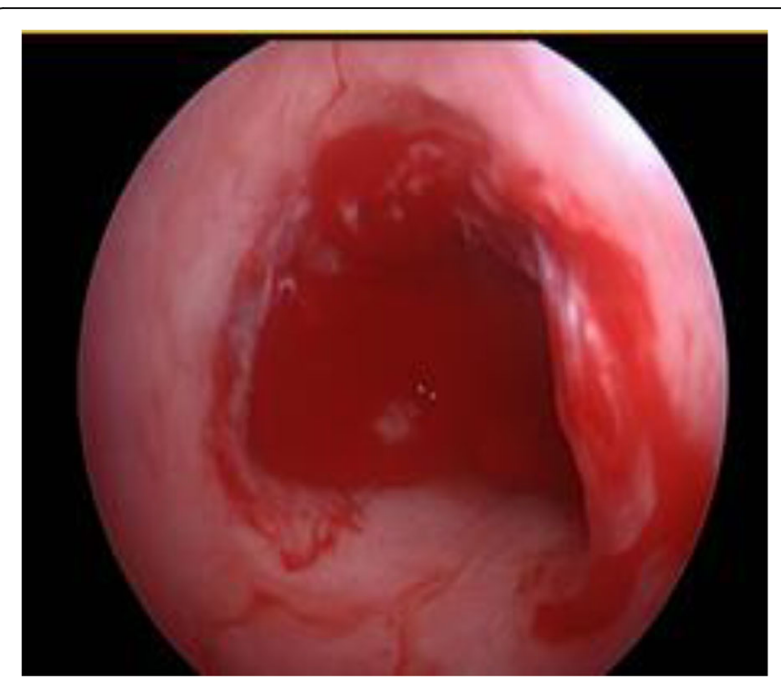

Fig. 4 Intraoperative transnasal endoscopy demonstrating post debriding adenoid bed through the left choana

curette had injured the mucosa near the eustachian tube. Also, there were 2 cases where the mucosa over the torus tubaris was abraded. In group A, the nasopharynx had no other injuries. However, 2 cases had a mild nasal mucosal injury (NMI) of the septum. No statistically significant difference between the two groups has been detected.

Postoperatively, patients were evaluated for postoperative pain where adenoidectomy alone was performed. Cases in which adenotonsillectomy was done were omitted, as tonsillectomy would have caused postoperative pain that could not be differentiated from postadenoidectomy pain; thus, group A (micro-debriderassisted) had only 8 patients, and group B (conventional) had only 11 patients. Both groups were contrasted, and statistical analysis demonstrated a pain score of 3.5-3.09 in group A (micro-debrider-assisted) and in group B (conventional) a pain score of 2.75-2.55. The pain scale used is the numeric rating scales (NRS). The patient rates his pain on a scale of 0 to 10 or 0 to 5 where zero means "no pain," and 5 or 10 means "the worst probable pain” (Table 3). In group A (micro-debrider-assisted), the mean postoperative recovery interval was 2.8 days while in group B (conventional), it was 8.23 days $(p<$ 0.001 ) which is statistically highly significant.

\section{Discussion}

Sleep-disordered breathing is a common indication for adenoidectomy because adenoidectomy accounted for an

Table 1 The mean operative time in both groups

\begin{tabular}{llllllll}
\hline Variables & Group & $\boldsymbol{N}$ & Mean & SD & Mean diff & $\boldsymbol{t}$ & $\boldsymbol{p}$ value \\
\hline Duration & Group A & 30 & 34.1 & 8.44 & 11.27 & 7.142 & $<0.001^{*}$ \\
& Group B & 30 & 22.83 & 1.86 & & & \\
\hline
\end{tabular}


Table 2 Comparison of residual adenoid tissue between two groups

\begin{tabular}{|c|c|c|c|c|c|c|}
\hline \multirow[t]{2}{*}{ Variables } & \multirow[t]{2}{*}{ Categories } & \multicolumn{2}{|c|}{ Group A } & \multicolumn{2}{|c|}{ Group B } & \multirow[t]{2}{*}{$p$ value } \\
\hline & & $N$ & $\%$ & $N$ & $\%$ & \\
\hline \multirow[t]{3}{*}{ Residual tissue } & Grade 1 & 30 & 100.0 & 7 & 23.3 & \\
\hline & Grade 2 & 0 & 0.0 & 18 & 60.0 & $<0.001^{*}$ \\
\hline & Grade 3 & 0 & 0.0 & 5 & 16.66 & \\
\hline
\end{tabular}

established role in these patients [13]. Various techniques have been described for adenoidectomy including the conventional method using adenoid curette and the described technique of power-assisted techniques with or without the use of the endoscope.

There are merits and drawbacks for each technique. In this study, the time of operation was significantly longer in group A (micro-debrider-assisted) than group B (conventional) the average operative time in group A was 34.1 min and in group B was $22.83 \mathrm{~min}$. Datta et al. showed that the average time of micro-debrider-assisted adenoidectomy was $39.3 \mathrm{~min}$ and the average time of conventional adenoidectomy was 29.3 min [14]. Contrary to this, Yang et al. reported that total operative time was longer in the conventional curettage adenoidectomy group than in the endoscopic assisted adenoidectomy group [15]. Another study by Al-Mazrou reported the same showing that the average operative time for micro-debrider-assisted adenoidectomy was $6.1 \mathrm{~min}$ while for the conventional adenoidectomy it was $12.3 \mathrm{~min}$ [16]. We attribute the increase in the operative time in the micro-debrider-assisted technique is quite explained by wise slow removal of the adenoid tissue and hemostasis which is time-consuming. Although the difference in time was statistically significant, the new technique only adds around $10 \mathrm{~min}$ to the mean operative time.

In this study, bleeding intra-operatively was significantly more in group A (micro-debrider-assisted) than group B (conventional), the average in group A was $29.57 \mathrm{ml}$ while in group B it was $16.67 \mathrm{ml}$. Intraoperative blood loss was more in group A because of increased operative time which leads to more time of exposure of the raw bleeding surface. However, AlMazrou et al. [16] reported that blood loss was more in conventional adenoidectomy, as it was $22.1 \mathrm{ml}$ while it

Table 3 Comparison of mean postoperative pain on day 1 and 7 between two groups using the Mann Whitney $U$ test

\begin{tabular}{llllllll}
\hline Variables & Group & $\boldsymbol{N}$ & Mean & SD & Mean diff & $\boldsymbol{t}$ & $\boldsymbol{p}$ value \\
\hline Pain day 1 & Group A & 8 & 3.5 & 1.77 & 0.41 & -0.456 & 0.65 \\
& Group B & 11 & 3.09 & 1.38 & & & \\
Pain day 7 & Group A & 8 & 2.75 & 1.49 & 0.20 & -0.270 & 0.79 \\
& Group B & 11 & 2.55 & 1.57 & & & \\
\hline
\end{tabular}

was $8.2 \mathrm{ml}$ in micro-debrider-assisted adenoidectomy. Stanislaw et al. had also similar results, reporting 27 percent less blood loss in micro-debrider-assisted adenoidectomy [17].

In this study, the post-procedure endoscopy showed that adenoid removal was almost complete in the endoscopic technique. Contradictory to this, more than 50 percent of adenoid tissue was left behind in 5 group B cases and between 20 and 50 percent of adenoid tissue was left in an additional 18 cases. This also ensures the capability of endoscopic assistance to achieve the complete removal of adenoid tissue. Havas et al. [18] reported residual adenoids in 39\% of cases following the conventional method. The authors have often noted that the extent of resection after conventional adenoidectomy was incomplete. Endoscopic evaluation was therefore considered to be used to determine the extent of residual tissue $[14,17,19-21]$. The nasopharynx can be clearly seen and the traces of adenoid tissue can be removed accurately under vision in endoscopic-assisted adenoidectomies. Thus, completeness is more in the endoscopic powered method.

Regarding injury to neighboring structures, an insignificant difference between both groups was found as 2 out of group A had an injury of the nasal mucosa while 4 out of group B had an injury. In 2 of them, there was a nasal mucosal injury and in the other 2 of them, there was an injury of the torus tubaris.

In this study, a non-significant difference in postoperative pain was found between both groups with less pain in micro-debrider-assisted adenoidectomy. Some studies also confirmed a similar result of less pain in the micro-debrider-assisted adenoidectomy group [14, 22].

Regarding the recovery time after any surgery, there is no unified parameter to use and different parameters are used by different studies, that is why, the recovery time is difficult to define. Following the surgery, in the postoperative follow-up, the question was raised about "return to normal daily activities." Regarding the recovery period, it was shorter for the micro-debrider-assisted adenoidectomy and there was a statistically significant difference. An average of 5 days faster recovery was accomplished by the use of debrider, which may favor an introduction to the newer methodology in current practices.

\section{Conclusion}

Endoscopic-powered adenoidectomy is a safe and reliable adenoidectomy technique. It provides complete and accurate removal, lesser injuries to collaterals, and a rapid recovery period. Conventional adenoidectomy, in contrast, scored higher regarding less operative time and intraoperative bleeding. 


\section{Abbreviations}

CA: Conventional adenoidectomy; FESS: Functional endoscopic sinus surgery; NMI: Nasal mucosal injury; NRS: Numeric rating scale

\section{Acknowledgements}

Not applicable

\section{Authors' contributions}

E A: Main supervisor, surgical procedures, data review. M K: Supervisor of research, surgical procedures, and data review. B A: Principal investigator, conduct of study, data collection. A E: Supervisor of research, surgical data. The author(s) read and approved the final manuscript.

\section{Funding}

The source of funding for this research is authors' personal funding

\section{Availability of data and materials}

The datasets used and/or analyzed during the current study are available from the corresponding author on reasonable request.

\section{Declarations}

\section{Ethics approval and consent to participate}

The name of ethics committee: ethics committee, Faculty of Medicine, Aswan University (IRB NO: 0006677809 (Expire June 10, 2021).

Consent to participate: Freely-given, informed consent to participate in this study was obtained from participants (or their parent or legal guardian in the case of children under legal age to consent).

\section{Consent for publication}

Not applicable.

\section{Competing interests}

The authors declare that they have no competing interests.

Received: 16 May 2020 Accepted: 5 April 2021

Published online: 05 June 2021

\section{References}

1. Evcimik MF, Dogru M, Cirik AA, Nepesov MI (2015) Adenoid hypertrophy in children with allergic disease and influential factors. Int J Pediatr Otorhinolaryngol 79(5):694-697[PubMed]. https://doi.org/10.1016/j.jporl.201 5.02 .017

2. Goeringer GC, Vidić B (1987) The embryogenesis and anatomy of Waldeyer's ring. Otolaryngol Clin N Am 20(2):207-217. https://doi.org/10.101 6/50030-6665(20)31638-8

3. Pereira L, Monyror J, Almeida FT, Almeida FR, Guerra E, Flores-Mir C, Pachêco-Pereira C (2018) Prevalence of adenoid hypertrophy: a systematic review and meta-analysis. Sleep Med Rev 38:101-112 [PubMed]

4. Kim JW, Kim HJ, Lee WH, Kim DK, Kim SW, Kim YH, Nam JG, Park SW, Park CS, Bae WY, Yeo NK, Won TB, Lee SH, Lee TH, Lee HJ, Kim SW, Jeong SW, Choi JS, Han DH, Choi JH (2015) Comparative study for efficacy and safety of adenoidectomy according to the surgical method: a prospective multicenter study. PLoS One 10(8):e0135304. https://doi.org/10.1371/journal. pone. 0135304

5. Koltai PJ, Discolo CM (2016) Current techniques of adenoidectomy Available from: http://pocketdentistry.com/current-techniques-of-adenoidectomy/

6. Meyer TA (1969) Meyer and the adenoids. Arch Otolaryngol 90(3):383-386

7. McClay JE, Meyers AD (2015) Adenoidectomy treatment \& management [Medscape]

8. Pagella F, Pusateri A, Canzi P, Caputo M, Marseglia A, Pelizzo G, Mattie E (2011) The evolution of the adenoidectomy: analysis of different power assisted techniques. Int J Immunopathol Pharmacol 24(4 Suppl):55-59. https://doi.org/10.1177/03946320110240S411

9. El Tahan AE, Elzayat S, Hegazy H (2016) Adenoidectomy: comparison between the conventional curettage technique and the coblation technique in pediatric patients. Egypt J Otolaryngol 32(3):152-155. https:// doi.org/10.4103/1012-5574.186528

10. Somani SS, Naik CS, Bangad CV (2010) Endoscopic adenoidectomy with microdebrider. Indian J Otolaryngol Head Neck Surg 62(4):427-431. https:// doi.org/10.1007/s12070-011-0118-9
11. Koltai PJ, Chan J, Younes A (2002) Power-assisted adenoidectomy: total and partial resection. Laryngoscope. 112(8):29-31

12. Pagella F, Pusateri A, Matti E, Giourgos G (2010) Transoral endonasalcontrolled combined adenoidectomy (TECCA). Laryngoscope. 120(10):20082010. https://doi.org/10.1002/lary.21070

13. Huang Q (2005) Clinical analysis of 68 patients with obstructive sleepdisordered breathing in children. Lin Chuang Er Bi Yan Hou Ke Za Zhi 19: 971-973

14. Datta R, Singh VP, Deshpal (2009) Conventional versus endoscopic powered adenoidectomy: a comparative study. Med J Armed Forces India 65(4):308312. https://doi.org/10.1016/S0377-1237(09)80089-0 Epub 2011 Jul 21. PMID: 27408282; PMCID: PMC4921343

15. Yang L, Shan Y, Wang S, Cai C, Zhang H (2016) Endoscopic assisted adenoidectomy versus conventional curettage adenoidectomy: a metaanalysis of randomized controlled trials. SpringerPlus 5(1):426. https://doi. org/10.1186/s40064-016-2072-1

16. Al-Mazrou KA, Al-Qahtani A, Al-Fayez Al (2009) Effectiveness of transnasal endoscopic powered adenoidectomy in patients with choanal adenoids. Int J Pediatr Otorhinolaryngol 73(12):1650-1652. https://doi.org/10.1016/j.jporl.2 009.08.019

17. Stanislaw PJ, Koltai PJ, Feustel PJ (2000) Comparison of power-assisted adenoidectomy vs adenoid curette adenoidectomy. Arch Otolaryngol Head Neck Surg 126(7):845-849. https://doi.org/10.1001/archotol.126.7.845

18. Havas T, Lowinger D (2002) Obstructive adenoid tissue: an indication for powered-shaver adenoidectomy. Arch Otolaryngol Head Neck Surg 128(7): 789-791. https://doi.org/10.1001/archotol.128.7.789

19. Koltai PJ, Kalathia AS, Stanislaw P, Heras HA (1997) Power-assisted adenoidectomy. Archives of otolaryngology. Arch Otolaryngol Head Neck Surg 123(7):685-688. https://doi.org/10.1001/archotol.1997.01900070023004

20. Hussein IA, Al-Juboori S (2012) Conventional versus endoscopic-assisted adenoidectomy: a comparative study. Med J Babylon 9:570-582

21. Prakash NS, Mallikarjunappa AM, Samuel HT (2013) Endoscopic assisted adenoidectomy versus conventional curettage adenoidectomy - a comparative study. Natl J Otolaryngol Head Neck Surg 1(suppl 10):10-12

22. Anand V, Sarin V, Singh B (2014) Changing trends in adenoidectomy. Indian J Otolaryngol Head Neck Surg 66(4):375-380. https://doi.org/10.1007/s12 070-013-0698-7

\section{Publisher's Note}

Springer Nature remains neutral with regard to jurisdictional claims in published maps and institutional affiliations.

\section{Submit your manuscript to a SpringerOpen ${ }^{\circ}$ journal and benefit from:}

- Convenient online submission

- Rigorous peer review

- Open access: articles freely available online

High visibility within the field

- Retaining the copyright to your article

Submit your next manuscript at $\boldsymbol{\nabla}$ springeropen.com 